УДК 347.454 (1-751.3)

JEL K 32, Q 38, Q 28, Q 29, Q 39

НІКОЛАЙЧУК Т.О.

магістр правознавства, аспірант

Інститут проблем ринку та економіко-екологічних досліджень НАНУ

Франиузький бульвар, 29, м.Одеса, Украӥна, 65044

E-mail:mazzi071988@gmail.com

Orcid.org/0000-0001-6268-7723

\title{
ХУМАРОВА H.I.
}

д-р екон. наук,

ст. наук. співроб.

Інститут проблем ринку та економіко-екологічних досліджень НАНУ

Франиузький бульвар, 29, м. Одеса, Україна, 65044

E-mail: oss_iprei@ukr.net

Orcid.org/0000-0001-5255-8004

\section{КОНТРАКТ - ЯК ІНСТРУМЕНТ ПОКРАЩЕННЯ УПРАВЛІННЯ ОБ'ЄКТАМИ ПРИРОДНО- ЗАПОВІДНОГО ФОНДУ}

\begin{abstract}
Актуальність. Ринкові перетворення в економіці країни викликали необхідність перегляду інституту трудових відносин з позииї економічного розвитку. Особливе значення набула теоретична переоцінка їх інституціональних засад: старі інститути трудового права, щзо відповідали командно-адміністративній системі, поступаються місцем новим, ще відповідають ринковим потребам. Одним з таких інститутів, щзо обумовлюють трудові відносини є контрактні відносини між роботодавцем та працівником, щзо дають змогу максимально персоналізувати трудовий потенціал, врахувати економічну зацікавленість обох сторін, та максимально захистити взаємні інтереси та права.

Мета та завдання. Метою статті є здійснити аналіз основних тенденцій та реалій використання роботодавиями такої особливої форми трудового договору - як контракт на підприємствах України, в частині укладення якого з керівником бюджетних установ за типовою формою, розглянути прогалини у чинному законодавстві, щчо стосуються інституту спеціалізації контракту, як особливої форми трудового договору з керівником підприємства та іншими категоріями працівників в залежності від специфіки діяльності підприємства або приналежності до сфери господарювання.

Результати. Визначено передумови імплементації спеціального законодавства під час укладення трудових договорів з керівниками підприємств, у площчині установ природно-заповідного фонду України. Також здійснено характеристику практичного застосування особливої форми трудового договору контракту адміністраціями установ природно-заповідного фонду у порівнянні з установами транспортної сфери. Розглянуто умови персоналізації відповідальності за порушення умов природоохоронного законодавства із визначенням сочіально-економічних складових.

Висновки. Імплементація інституту контрактних відносин у сферу природно-заповідного фонду сприяла б прозорості, законності побудови таких відносин, надала б змогу більшій кількості осіб реалізувати свої здібності до праці на найбільш вигідних умовах. Застосування контракту як особливої форми трудового договору - максимально деталізує трудові відносини, розширює систему економічного стимулювання та заохочення працівників, захищає права як співробітника, так і роботодавцุя, а також надає можливість оцінити ступінь взаємної відповідальності.
\end{abstract}

Ключові слова: трудовий договір, персоніфікація відповідальності, транспорт, економічна дочільність, роботодавець, трудові спори, засоби економічного стимулювання, персоналізачія трудових відносин.

\section{NIKOLAJCHUK T.O.}

Master of Law, postgraduate

Institute of Market Problems and Economic-Ecological Researches of the

National Academy of Science of Ukraine

29 Frantsuzkyj boulevard, 65044, Odessa, Ukraine

E-mail: mazzi071988@gmail.com

Orcid.org/0000-0001-6268-7723 


\author{
KHUMAROVA N.I. \\ Dr.Sc. (Economics), \\ Institute Of Market Problems And Economic\&Ecological Research of the \\ National Academy Of Sciences Of Ukraine \\ Frantsuzskiy Boulevard, 29, Odessa, Ukraine \\ E-mail: oss_iprei@ukr.net \\ Orcid.org/0000-0001-5255-8004
}

\title{
CONTRACT - A TOOL FOR IMPROVING MANAGEMENT OF THE NATURAL RESERVE FUND
}

Topicality. Market transformations in the country's economy caused the need to revise the labor relations institute from the economic development point of view. Particular importance was the theoretical reassessment labor relations institutional: the old labor law institutes, which corresponded to the administrative command system, must transform to new ones, that contain market needs. One of such labor relations institutes are contractual relations between the employer and the employee, which allow to personalize the labor relations as much as possible, consider the economic interest of both parties, and protect as far as possible the mutual interests and rights.

Aim and tasks. The aim of the article is represented the main tendencies and realities of using an employment contract in Ukraine's companies, which is signed in the standard form. The current legislation gaps of the contract using are considered as a special employment contract form with the companies leaders and other employees categories, depending on the specifics enterprise's activity or belonging to the management sphere. The preconditions for the special legislation implementation are determined during the labor contracts conclusion with the Ukrainian's nature reserve fund enterprises heads. The personal responsibility for environmental protection legislation and violation conditions are considered. Proactive and experienced specialists are established an extensive system of allowances and one-time incentives.

Research results. In this article we have reviewed the implementation preconditions during the labor contracts' conclusion with the enterprises' heads of the Ukrainian nature reserve fund. We have considered the responsibility personalization conditions for environmental legislation violations with the definition of socio-economic components. For example, the contract may also stipulate social and living conditions, such as the garden plot allocation, a car, living conditions improvement, the share sale at par value, the social pensions surcharges establishment, protection against inflation processes and so on. Also it may be envisaged an employee to move another area.

Conclusions. A contract can give the chance to more people to realize their work abilities on the most favorable conditions, to build the civil society foundations and the legal capitalist state. Contract's application can detail the labor relations, the system of economic incentives and encouragement, protects the rights of both employee and employer, and also provides an opportunity to assess the mutual responsibility's degree.

Keywords: labor contract, responsibility personification, transport, economic feasibility, employer, labor disputes, means of economic stimulation, labor relations' personalization.

Постановка проблеми та її зв'язок 3 важливими науковими та практичними завданнями. В сучасних умовах розвитку інституту найманої праці все частіше вітчизняні роботодавці звертаються до такої форми відносин 3 працівником, як контракт. Відповідний вид трудового договору дає можливість передбачити набагато більше аспектів взаємовідносин між роботодавцем та працівником, а також вказати реальні підстави припинення цих відносин, що забезпечить зниження випадків зловживання владою зі сторони роботодавця та обмеження порушень норм закону з боку некваліфікованого працівника. Крім того укладення такої особливої форми трудового договору як контракт має певне економічне підгрунтя для роботодавця, якщо мова йде про бюджетні установи, та держави в цілому, тому що роботодавець може чітко регламентувати трудові відносини залежно від кваліфікації працівника, посади у штатному розкладі, істотних умов праці,відповідальності сторін, умов дострокового припинення трудових відносин, наданням додаткових пільг, гарантій, покращенням соціально побутових умов тощо. При цьому роботодавець не порушує жодних прав або свобод майбутнього працівника, та має можливість підібрати кваліфікованих співробітників суттєво знижуючи ризик виникнення судових спорів та як наслідок витрачання бюджетних коштів на судову тяганину. Однак багато проблем, пов'язаних з розробленням, оформленням та укладенням такої особливої форми трудового договору, як контракт, для певних видів економічної діяльності або галузі, залишаються не вирішеними. Таким чином можна зробити висновок, що відповідне питання $є$ дуже актуальним не тільки для окремих галузей народного господарства, а для держави в цілому.

Аналіз останніх публікацій по проблемі. Вивченню питань щодо процедури імплементації та доцільності застосування контрактних відносин займалися Н. Болотіна, А. Кулініч, С. Селезень, М.Волянський, І.Боханова, А.Луценко, В.Прокопенко, О.Гаврилюк, А.Ставцева, І.Зуб, В.Ротань, 
Б.Стичинський, П.Пилипенко, З.Козак, Д.Лещук, Т.Парпан. Зокрема Н.Болотіна вказала на виникнення великої кількості правових питань під час застосування контрактів, зокрема не тільки 3 позитивної сторони в контексті індивідуалізації трудових відносин, але наявності чималої кількості негативних наслідків для працівників [1, с. 238]. А.Луценко фокусує проблему визначення правової сутності контракту, зокрема його деталізації [2, с. 44 ]. О.Гаврилюк намагається провести відмінності між поняттям "контракт" та "письмовою формою строкового трудового договору" на підставі прояву волі сторін [3, с. 75].

Аналіз норм чинного законодавства також свідчить, що застосування контрактних відносин має чимало прогалин в сьогоденних реаліях. Кодексом законів про працю України, який діє з 1971 року, визначення загальне поняття такої особливої форми трудового договору, як контракт. Постановою Кабінету Міністрів України від 02.08.1995 № 597 «Про Типову форму контракту з керівником підприємства, що є у державній власності» передбачено типову форму контракту з керівником без урахування специфіки діяльності підприємства та сфери народного господарства. Постановою Кабінету Міністрів України від 19.03.1994р. № 170 "Про впорядкування застосування контрактної форми трудового договору", Постановою Пленуму ВСУ № 9 від 06.11.1992p. «Про практику розгляду судами трудових спорів» визначено порядок дострокового припинення трудових відносин 3 працівником у разі порушення умов контракту.

Виділення невирішених раніше частин загальної проблеми. Упровадження контрактної форми в трудових правовідносинах обумовлено прагненням роботодавців залучати до роботи найкваліфікованіших i творчо найактивніших працівників, а також 3 метою захисту власних економічних інтересів. Отже, виникає необхідність створення правового механізму, за допомогою якого можна було б усунути економічні, юридичні та організаційні обмеження, що перешкоджають роботодавцю та майбутньому працівнику здійснювати взаємодію на найбільш вигідних умовах. Контракт як нова форма регулювання трудових правовідносин передбачає більшу гнучкість в умовах наймання працівників, режиму їх трудової діяльності, основних прав та обов'язків, істотних умов праці, системи економічного стимулювання працівників, умов притягнення до юридичної відповідальності. На сьогоднішній день при застосуванні контрактної форми відносин має бути враховано галузеву спрямованість підприємства, установи, організації, особливості покладених на підприємство функцій, норм права, які регламентують роботу установи, режим роботи, економічну та соціальну складову діяльності. Контракти, які укладаються 3 керівниками або окремими посадовими особами установ природно-заповідного фонду, установ транспорту та зв'язку або харчової промисловості не мають бути тотожними або уніфікованими, оскільки коло обов'язків, сфера повноважень, система соціально-економічних заохочень і як наслідок відповідальність $\epsilon$ діаметрально протилежними, та не можуть міститись в одному нормативно-правову акті, хоч би який він грунтовний не був.

Формулювання цілей дослідження. В даному дослідженні пропонується розглянути поняття такої особливої форми строкового трудового договору як контракт крізь призму законодавчої спеціалізації, враховуючи економічні чинники роботи підприємства та сфери народного господарства до якої воно належить, на прикладі установ природно-заповідного фонду України. Також провести порівняння з галузями вітчизняного законодавства, де контрактна форма трудових відносин набула широкого розповсюдження, відповідає особливостям роботи та функціонування підприємств, зокрема транспортного та суміжних галузей законодавства. Розглянути розгалужену систему соціально-економічних заохочень працівників в залежності не тільки від об'єму та якості виконуваних функцій за основним місцем роботи, але також громадської, інформаційно-освітньої, виховної, наукової та соціальної діяльності на підприємстві.

\section{Виклад основного матеріалу.}

Контрактна форма трудового договору дає можливість раціонально регулювати чисельність та якісний склад персоналу, поліпшувати структуру зайнятості, в разі потреби додатково залучати кваліфікованих працівників зі сторони. Перевага контракту перед звичайним трудовим договором полягає в тому, що це дає змогу максимально індивідуалізувати кожну конкретну угоду про працю, наповнити іiі специфічним змістом, врахувати усі особливості відносин 3 кожним окремим працівником, детально регламентувати права та обов'язки обох сторін, режим праці й відпочинку, соціально-побутові умови, форму й розмір отриманої винагороди за роботу, додаткової винагороди за певні досягнення, пільги, превенції та інші додаткові умови.

Контракт як особливий вид трудового договору почав укладатися з керівниками державних підприємств 31990 року, коли була прийнята Постанова Ради Міністрів СРСР «Про порядок найму і звільнення керівника державного союзного підприємства». Відповідний нормативний акт не $\epsilon$ 
результатом простого співпадіння юридичних фактів та соціально-економічних обставин в державі. На процедуру укладення трудового договору (контракту) з особами, що призначаються на керівні посади варто звернути особливу увагу, оскільки при розгляді кандидатів на посади керівників різних рівнів може мати місце зловживання нормами права, використання прогалин та колізій у чинному законодавстві, чи навіть корупційний елемент. Це пов'язано насамперед 3 тим, що особи які займають керівні посади мають більш високий рівень знань, як юриспруденції так і загальних дисциплін, а також можливості та ресурси щодо оскарження процедури звільнення або притягнення до дисциплінарної відповідальності у судовому та позасудовому порядку. Крім того на сьогоднішній день українські реалії показують нам, що необгрунтовано застосовується спрощена та занадто уніфікована форма контракту з керівниками установ, без урахування сфери господарської діяльності підприємства, особливостей роботи як установи в цілому, так і ії керівника, не враховуються норми спеціального законодавства, економічна складова діяльності установи.

Особливого значення це набуває для керівників, які займають посади директорів установ природно-заповідного фонду в контексті переходу країни до сталого розвитку. Захист природного біорізноманіття та його відтворення $\epsilon$, на сьогоднішній день, одним з пріоритетних напрямів політики держави, тому важливо, щоб такі посади займали особи дійсно кваліфіковані особи, а трудові відносини мали прозорий та чітко регламентований характер. Керівники природоохоронних установ, це окрема ланка управлінської системи України, вкрай важливо, щоб кандидат, який претендує на посаду директора об'єкта природно-заповідного фонду чітко розумів межі своєї відповідальності перед народом України в цілому, та не мав змоги уникнути юридичної відповідальності через казуїстичність та нечіткість норм чинного законодавства.

Природо-заповідним законодавством передбачено, що управління природними заповідниками, біосферними заповідниками, національними природними парками, ботанічними садами, дендрологічними та зоологічними парками загальнодержавного значення, а також регіональними ландшафтними парками здійснюється їх спеціальними адміністраціями. Спеціальні адміністрації мають очолювати керівники, які мають екологічну, біологічну або географічну освіту та призначатися за погодженням із центральним органом виконавчої влади в галузі охорони навколишнього природного середовища. Спеціальні адміністрації, згідно вимог чинного законодавства, здійснюють управління територіями та об'єктами природно-заповідного фонду відповідно до положень про території та об'єкти природно-заповідного фонду i проектів організації територій та об'єктів природно-заповідного фонду[4].

На цьому спеціальна регламентація діяльності керівництва установ природно-заповідного фонду вичерпується. В інституційному забезпеченні відсутні норми права чи посилання не тільки у національному але й міжнародному законодавстві, яке регламентує діяльність керівництва вищого рівня установ природно-заповідного фонду. Отже, дуже актуальним $є$ дослідження питання укладення контракту з керівниками установ природно-заповідного фонду через призму спеціалізації, розробки чіткого алгоритму відповідальності цих посадовців, але при цьому не порушуючи їх трудові права.

На сьогоднішній день законодавчо затверджено типову форму контракту 3 керівником підприємства, що є у державній власності, який має стандартну структуру без урахування специфіки роботи природоохоронних установ, в тому числі установ природно-заповідного фонду. Цим нормативно-правовим актом передбачено, основні підстави, коли керівник може бути звільнений 3 посади, а цей контракт розірваний 3 ініціативи Органу управління майном, у тому числі за пропозицією місцевого органу державної виконавчої влади, до закінчення терміну його дії. Зазначені у типовій формі договору підстави носять загальногосподарський характер, та притаманні усім підприємствам держави без винятку [5], тобто взагалі не враховують специфіку роботи установ природно-заповідного фонду та ступінь відповідальності керівника установи саме за природоохоронну,відтворювальну, еколого-економічну, рекреаційну та освітню-інформаційну складову діяльності об’єктів природно-заповідного фонду.

Нормами законодавства передбачено таке загальне і об'ємне, можна навіть зауважити, абстрактне поняття - «інші підстави» розірвання трудового договору. Але на практиці відповідний пункт або взагалі ігнорується з боку органу управління майном, оскільки не є обов'язковим, або підстави мають суто декларативний, формальний характер та не відображають суті діяльності керівника та випадки настання «спеціальної відповідальності». Це може бути пов'язано 3 корупційною складовою призначення особи на посаду керівника установи природно-заповідного фонду, лобіюванням інтересів певних політичних угрупувань та навмисним зниженням рівня відповідальності перед законом та суспільством, нерозуміння працівниками кадрових підрозділів 
особливостей природоохоронної, рекреаційної, еколого-економічної, освітньої та іншої діяльності повною мірою, для доповнення контракту такими пунктами, які б відповідали реаліям роботи установ природо-заповідного фонду. В останньому випадку варто зазначити, що співробітники кадрових служб, бухгалтерії або навіть юрисконсульти підприємств не мають необхідності володіти у повній мірі специфікою екологічної, природоохоронної чи рекреаційної діяльності. Тому наявність закріпленого на законодавчому рівні грунтовного, детального, структурованого, відповідно до специфіки функціонування установ природно-заповідного фонду, контракту з керівником установи природно-заповідного фонду, розкриває інституційні засади та сприяє розв'язанню багатьох проблем. Це саме стосується інших категорій посадових осіб, зокрема служби державної охорони, що значно впливатиме на організацію їх діяльності та відповідальності за прийняття управлінських рішень.

Аналіз роботи об'єктів природно-заповідного фонду вказує, що в таких установах ще низка посадових осіб, регламентація діяльності яких носить поверхневий характер, зокрема головний природознавець, начальник відділу державної охорони, начальник відділу збереження/відтворення/охорони/використання природних екосистем, начальники природоохоронних науково-дослідних відділень, інші посадові особи служби державної охорони та керівники відділів рекреації.

Особливо актуальним є обгрунтоване та закріплене визначення відповідальності працівників служби державної охорони, оскільки вони відповідно до законодавства мають права складати протоколи про порушення адміністративного законодавства в галузі охорони довкілля і використання природних ресурсів, вилучати у порушників предмети i знаряддя незаконного використання природних ресурсів, транспортні засоби, незаконно добуту продукцію, відповідні документи, проводити особистий огляд осіб, речей, транспортних засобів та перевірку знарядь і продукції, одержаної в результаті природокористування, безперешкодно перевіряти підприємства, установи, організації, судна та інші транспортні засоби у межах територій та об'єктів природно-заповідного фонду, їх охоронних зон стосовно додержання вимог природоохоронного законодавства, надавати обов'язкові для виконання приписи з метою усунення порушень, виявлених у межах територій та об'єктів природно-заповідного фонду, носити під час виконання службових обов'язків табельну зброю та багато інших повноважень[6].

3 метою удосконалення системи управління екологічною безпекою, іiі прозорого регулювання 3 боку державних органів та громадських організацій діяльності вищезазначених посадових осіб, доцільно було б розробити перелік посад професій працівників заповідної справи, які мають працювати за контрактною формою та запропонувати типову форму трудового договору (контракту) для кожної категорії працівників з урахуванням особливостей їх функціональних обов'язків.

Наразі законодавець ставить досить узагальнені вимоги до посад працівників, не містить посилань на спеціалізоване законодавство, та багато в чому не враховує реалій сьогодення [7]. Уникнути прогалин під час складення посадових інструкцій допоможе розробка типової форми посадових інструкцій зокрема для таких категорій посад працівників, як директор установи природно-заповідного фонду, головний природознавець, начальник служби державної охорони, начальник природоохоронного науково-дослідного відділення, начальник відділу збереження (відтворення) природних екосистем, начальник відділу використання природних ресурсів, майстер 3 охорони природи, інспектор з охорони природно-заповідного фонду, керівник відділу рекреації.

Зараз посадові інструкції працівників складаються адміністраціями установ природнозаповідного фонду у довільній формі, не носять уніфікованого характеру, а кадрові робітники не завжди володіють у повній мірі специфікою роботи охоронних та рекреаційних відділів установи.

Враховуючи вищевикладене в разі порушення трудових обов'язків відповідними працівниками та, як наслідок, розірвання з ними трудового договору виникає чимало судових спорів. Недосконалі 3 позиції економічного, економіко-екологічного забезпечення, вимог чинного законодавства посадові інструкції унеможливлюють притягнення до відповідальності порушника трудової дисципліни, або не враховують причинно-наслідковий зв'язок між тяжкістю дисциплінарного проступку та мірою дисциплінарної відповідальності за нього. Все це призводить до економічних збитків установ природно-заповідного фонду.

Судова статистика свідчить про велику кількість поновлення раніше звільнених працівників, та відшкодування чималих сум за вимушений прогул та компенсацію моральної відповідальності. Кошти поновленим працівникам сплачуються за рахунок Державного бюджету України [8], в той же час при якісному та прозорому оформленні трудових відносин та зменшенні поновлень на роботі, ці кошти можна спрямувати на природоохоронну, еколого-відтворювальну, рекреаційну, наукову діяльність, тощо. 
Хотілося б звернути увагу на суміжну галузь законодавства України, а саме транспортне законодавство, тому що в цій царині набули широкого розповсюдженні контрактні відносини 3 працівниками. Підзаконними нормативними актами індивідуалізовано трудові відносини, в частині прав та обов'язків працівників та роботодавця, надання пільг, соціального забезпечення, побутових умов,чинників економічного стимулювання та заохочення працівників, грошової винагороди, а також ступінь взаємної відповідальності сторін [9]. В таблиці 1 представлено порівняння нормативно правових актів щодо формування контрактних відносин в транспортній та природоохоронній галузях.

Таблиця 1

Основні положення нормативно-правових актів щодо формування контрактних відносин в транспортній та природоохоронній галузях

\begin{tabular}{|c|c|c|c|c|}
\hline $\begin{array}{l}\text { Нормативно } \\
\text {-правовий } \\
\text { акт }\end{array}$ & $\begin{array}{c}\text { Природоохоронна } \\
\text { галузь }\end{array}$ & 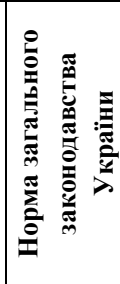 & 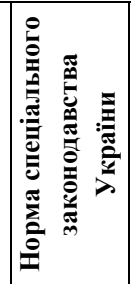 & 总 \\
\hline $\begin{array}{l}\text { Кодекс } \\
\text { законів про }\end{array}$ & $\begin{array}{l}\text { Ст.21 КЗПП України передбачено, трудовий договір є } \\
\text { угода між працівником і власником }\end{array}$ & + & & \\
\hline \multirow[t]{2}{*}{$\begin{array}{l}\text { працю України } \\
\text { від 10.12.1971p }\end{array}$} & $\begin{array}{l}\text { підприємства, установи, організації або } \\
\text { уповноваженим ним органом чи фізичною особою, за } \\
\text { якою працівник зобов'язується виконувати роботу, } \\
\text { визначену цією угодою, з підляганням внутрішньому } \\
\text { трудовому розпорядкові, а власник підприємства, } \\
\text { установи, організації або уповноважений ним орган } \\
\text { чи фізична особа зобов'язується виплачувати }\end{array}$ & & & \\
\hline & $\begin{array}{l}\text { працівникові заробітну плату і забезпечувати умови } \\
\text { праці, необхідні для виконання роботи, передбачені } \\
\text { законодавством про працю, колективним договором і } \\
\text { угодою сторін [10]. }\end{array}$ & & & \\
\hline $\begin{array}{lr}\text { Постанова Пле- } \\
\text { нуму } \\
\text { Верхов- } \\
\text { Ного } \\
\text { України } \\
\text { листопу } \\
\text { року } & 1992 \\
\text { практику } & \text { «роз } \\
\text { гляду трудових } \\
\text { спорів» }\end{array}$ & 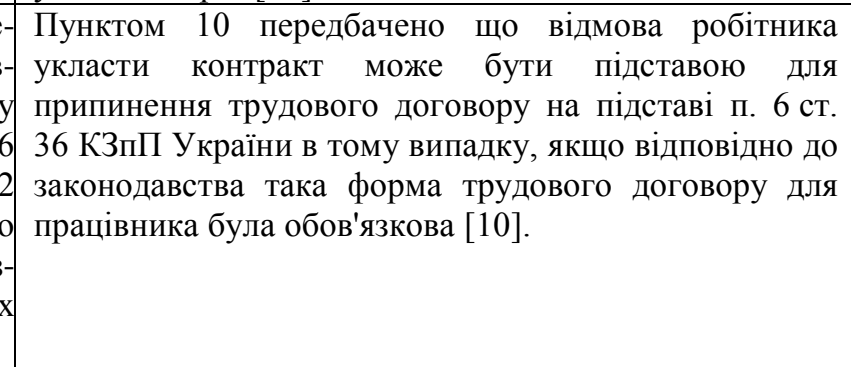 & + & & \\
\hline $\begin{array}{l}\text { Постанова } \\
\text { КМУ "Про } \\
\text { впорядкування } \\
\text { застосування } \\
\text { контрактної } \\
\text { форми } \\
\text { трудового } \\
\text { договору" від } \\
19 \quad \text { березня } \\
1994 \text { р. N } 170\end{array}$ & $\begin{array}{l}\text { Пунктом } 9 \text { передбачено, що контракт набуває } \\
\text { чинності } 3 \text { моменту його підписання або } 3 \text { дати, } \\
\text { визначеної сторонами у контракті, і може бути } \\
\text { змінений за згодою сторін, складеною у письмовій } \\
\text { формі. Контракт є підставою для видання наказу } \\
\text { (розпорядження) } \text { про прийняття (найняття) } \\
\text { працівника на роботу } 3 \text { дня, встановленого у } \\
\text { контракті за угодою сторін [11]. }\end{array}$ & + & & \\
\hline "-" & $\begin{array}{l}\text { Пунктом } 17 \text { передбачено, що у контракті можуть } \\
\text { визначатися додаткові, крім встановлених чинним } \\
\text { законодавством, підстави його розірвання." }\end{array}$ & + & & \\
\hline $\begin{array}{l}\text { Конвенція } \\
\text { МОП № } 158 \\
\text { про } \\
\text { припинення } \\
\text { трудових } \\
\text { відносин } \\
\text { ініціативи } \\
\text { роботодавця, } \\
\text { ратифікованої }\end{array}$ & $\begin{array}{l}\text { Працівник, з яким намічено припинити трудові } \\
\text { відносини має бути попереджений про це за } \\
\text { розумний строк [12]. }\end{array}$ & + & & \\
\hline
\end{tabular}


(продовження таблиці 1)

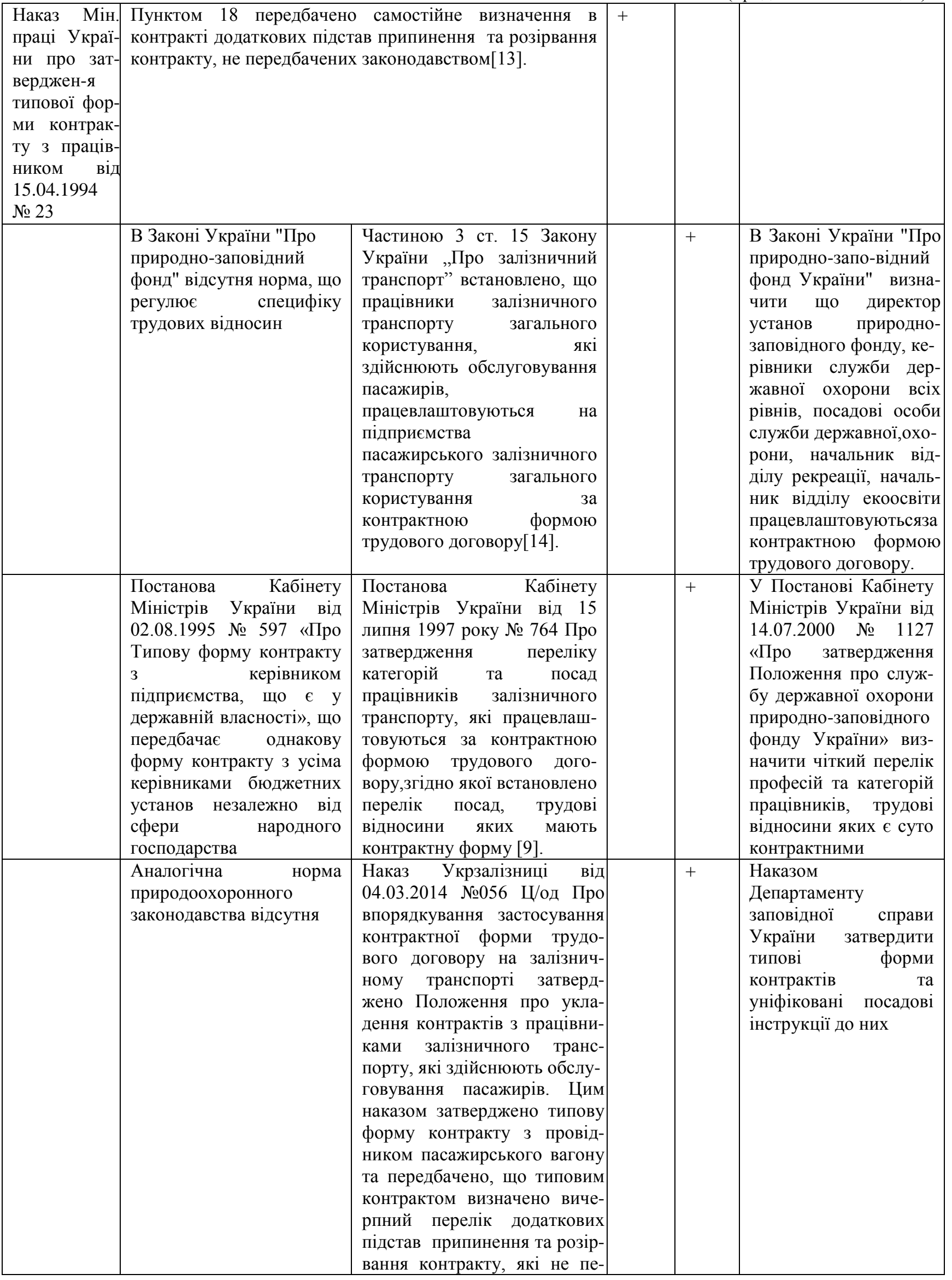




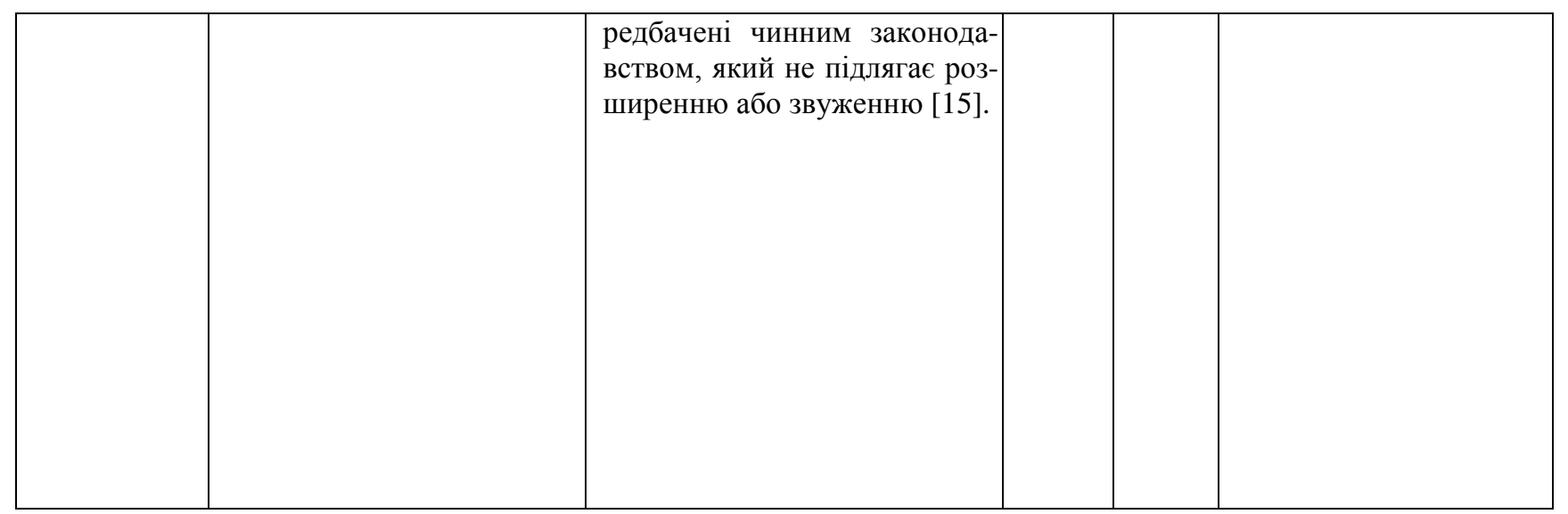

Аналізуючи відповідну таблицю ми бачимо, що у сфері природно-заповідної справи взагалі відсутні норми спеціального призначення, а отже при складанні посадових інструкції, потім, як наслідок контрактів адміністрації установ природно-заповідного фонду мають керуватись власними знаннями природоохоронного, екологічного, трудового, цивільного,господарського, фінансового законодавства, аналогією закону, набутим досвідом.

Для прикладу розглядаючи Постанову Кабінету Міністрів України від 02.08.1995 № 597 "Про типову форму контракту з керівником підприємства, що є у державній власності" [5] та наказ Міністерства праці України від 15.04.1994 № 23 "Про затвердження типової форми контракту 3 працівником" [13] ми бачимо, що законодавець залишив питання відповідальності працівника (дострокового розірвання контракту) на власний розсуд адміністрацій підприємств. Розробляючи контракт адміністрація підприємств може додати підстави його дострокового розірвання керуючись власними знаннями галузевого господарства та особливостей роботи певної категорії професії працівника чи навіть "внутрішнім переконанням", що може дуже негативно вплинути на трудові відносини. По-перше працівниками кадрової служби можуть бути включені пункти, які не стосуються роботи даної категорії професій чи посад, або не врахувати всі обов'язки покладені на працівника, чи навіть навмисно знизити або штучно збільшити ступінь відповідальності. Також варто розглянути галузевий нормативний акт, а саме Наказ Державної адміністрації залізничного транспорту України від 04.03.2014 № 056Цод "Про впорядкування застосування контрактної форми трудового договору на залізничному транспорті" [15]. В даному випадку законодавцем розроблено галузевий нормативний акт, який регулює "проблемні" відносини між роботодавцем і працівником, та максимально знижує ризики включення до контрактів пунктів, які суперечать вимогам законодавства та можуть порушувати ї права. Контрактом укладеним між роботодавцем та працівником, на підставі типової форми контракту, передбачено що працівник може бути звільнений, а контракт розірваний з ініціативи роботодавця до закінчення терміну його дії у разі: встановлення факту перевезення безквиткових пасажирів. Із зазначеного слідує, що для наявності у роботодавця підстав розірвати даний контракт достатньо встановити факт перевезення безквиткових пасажирів. Під час прийняття на роботу та укладення контракту 3 адміністрацією підприємства працівник повністю погоджувався на визначені умови праці, жодну з додаткових підстав розірвання трудового договору достроково не оскаржував. Тобто у разі порушення вимог контракту адміністрація установи залізничного транспорту має законну підставу для звільнення такого працівника, що знижує рівень поновлень за рішенням суду, та можливості маніпулювання нормами права з боку колишніх працівників. Крім того під час прийняття на посаду кандидат одразу розуміє ступінь відповідальності перед підприємством. А оскільки з працівниками також можуть укладатися договори про повну індивідуальну матеріальну відповідальність, адміністрація установ залізничного транспорту також має можливість вимагати відшкодування збитків завданих під час виконання функціональних обов'язків у судовому порядку.

Рішенням Конституційного суду України дано офіційне тлумачення частини третьої статті 21 Кодексу законів про працю України, що під час укладання ними трудових договорів у формі 
контрактів, сторонами в контракті можуть передбачатися невигідні для працівника умови: зокрема, це, як правило, тимчасовий характер трудових відносин, підвищена відповідальність працівника, додаткові підстави розірвання договору тощо [16].

Крім того варто звернути увагу на засоби економічного, соціально - побутового стимулювання працівників установ природно-заповідного фонду. Гідне економічне, соціально-побутове заохочення співробітників дає змогу утримати вже існуючи досвідчені та кваліфіковані кадри, а також залучити молодих, амбітних та професійних працівників, які володіють передовими інноваційними знаннями, а також звільнені від тягаря командно-адміністративної побудови трудових відносин минулого. Використовуючи контрактні відносини та індивідуалізуючи трудові відносини 3 працівниками шляхом фінансово-економічних заохочень, адміністрації установ природно-заповідного фонду можуть зацікавити не тільки менеджерів вищих ланок, але й фахівців рідкісних спеціальностей або тих, хто навчався чи підвищував кваліфікацію у європейських вишах, має досвід роботи за кордоном та загалом підвищити престиж роботи в установах природно-заповідного фонду.

Проведений аналіз інституціональної бази вказує на таке: нормативно правові акти не конкретизовані, законодавець не намагається індивідуалізувати відносини в рамках хоч би однієї галузі, чи сфери національного господарства. Норми законодавства залишились у спадок 3 Радянського Союзу, є казуїстичними, містять чимало прогалин та колізій, не відповідають змісту ринкових відносин між роботодавцем та працівником. Трудові відносини носять відбиток адміністративно-командної системи управління, коли приймаючи працівника на роботу роботодавець здебільшого не має змоги розірвати трудові відносини у законній площині, навіть якщо через деякий час ефективність та ініціативність працівника знижується, або взагалі працівник працює суто формально. Зауважимо, що контракт, як особлива форма трудового договору має забезпечувати умови для виявлення ініціативності й самостійності працівника, враховуючи його індивідуальні здібності й професійні навички, підвищення взаємної відповідальності сторін, економічну, фінансову, правову й соціальну захищеність працівника. В разі розробки на галузевому рівні типових форм контрактів, в залежності від вимог до професій, посад, ступеню відповідальності, обсягу повноважень, економічного, соціально - побутового забезпечення законодавець зможе уникнути безпідставних судових спорів, втрати фінансових ресурсів підприємства, зменшити навантаження на судову систему, скоротити обсяг витрат з Державного або місцевих бюджетів на відшкодування шкоди працівникам.

На сьогоднішній день надважливо персоналізувати трудові відносини з керівниками, оскільки саме вони відіграють величезну роль у забезпеченні діяльності будь-якого підприємства, установи, організації, здійснюючи функції управління юридичною особою. Керівник має особливий юридичний статус, що зумовлюється тим, що він одночасно $є$ i органом юридичної особи, і найманим працівником, який сам перебуває у трудових правовідносинах з власником такої юридичної особи $[17$, с. 221$]$. Особливий правовий статус керівника юридичної особи в незалежності від форми власності зумовлює особливості правового регулювання його праці, зокрема, певні особливості контрактної форми трудового договору, що з ним укладається.

Ускладнення питання стосовно регулювання трудових відносин з керівником юридичної особи пов'язано з тим, що вітчизняне законодавство не приділяє уваги щодо регулювання праці керівної ланки підприємства, установи та організації, жодним нормативно-правовим актом не визначено правового статуту такого працівника [18, с. 166-167].

Контракт $є$ необхідним і дієвим регулятором трудових правовідносин керівників підприємств, оскільки саме за допомогою контракту відбувається посилення індивідуально-договірного регулювання трудових правовідносин шляхом встановлення необхідних та додаткових умов праці та всіх відносин, пов'язаних із виконанням зобов'язань [19, с. 300].

Керівник підприємства, установи, організації, здійснюючи управлінську діяльність, є найважливішою ланкою в діяльності підприємства, від рішень та дій керівника буде залежати результативність діяльності юридичної особи, у зв'язку із чим власник підприємства (установи, 
організації) зацікавлений у найбільш кваліфікованих керівниках, які мають найвищий рівень професіоналізму, можуть самостійно приймати відповідальні рішення і відповідно несуть за такі свої дії підвищену відповідальність. Таким чином, контракт у першу чергу використовується роботодавцями при їх заінтересованості взяти до себе на роботу найбільш компетентних, кваліфікованих і досвідчених працівників, таких керівників, які належним чином спрямовуватимуть діяльність підприємства. Контракт надає можливість врахувати особливості такої категорії працівників, як керівник, оскільки діючим трудовим законодавством в Україні жодним чином не враховуються особливості роботи таких працівників, що є значним недоліком [18, с. 167].

Зокрема у царині природно-заповідної справи доцільно розробити уніфіковану посадову інструкцію та затвердити типову форму контракту з керівниками установ природно-заповідного фонду, головним природознавцем та іншими категоріями посад, як наприклад начальник відділу державної охорони/збереження/відтворення/використання природних ресурсів/екосистем, начальник природоохоронного науково-дослідного відділення, начальник відділу рекреації, завідувач розплідника, менеджер в сфері використання природних ресурсів, майстер 3 охорони природи, інспектор-природоохоронного науково-дослідного відділення тощо. Контракт 3 кожною категорією професій посад працівників максимально деталізує трудові відносини, розширює систему економічного стимулювання та заохочення працівників, захищає права як співробітника, так i роботодавця, а також надає можливість оцінити ступінь взаємної відповідальності.

До прикладу контракт 3 керівником установи природно-заповідного фонду може бути розірваний достроково, а він звільнений з посади 3 наступних підстав не передбачених чинним законодавством:

- дозвіл на проведення короткострокового відпочинку на території не передбаченій для цього положенням про територію або об'єкт природно-заповідного фонду та проектом організації території чи об'єкту природно-заповідного фонду (наприклад поза межами господарської зони національних природних парків);

- дозвіл на спеціальне використання природних ресурсів поза межами ліміту на їх використання;

- нераціональний розподіл обсягів спеціального використання природних ресурсів між суб'єктами господарювання;

- порушення процедури спеціального використання природних ресурсів на території об'єкту природно-заповідного фонду, яке здійснюється на підставі дозволів;

- навмисне подання недостовірної або неповної інформації під час участі у здійсненні оцінки впливу на довкілля об'єктів, що негативно впливають чи можуть негативно вплинути на стан територій та об'єктів природно-заповідного фонду;

- систематичне порушення вимог режиму територій та об'єктів природно-заповідного фонду;

- дозвіл на проведення господарської або будь-якої іншої діяльності, що суперечить цільовому призначенню об'єкта природно-заповідного фонду;

- порушення вимог щодо збереження і відтворення корінних або рідкісних природних комплексів та об'єктів;

- порушення вимог щодо здійснення протипожежних заходів на території об'єкту природнозаповідного фонду, що спричинило негативні наслідки для природних комплексів та екосистеми в цілому;

- порушення вимог щодо створення умов для організованого туризму, відпочинку та інших видів рекреаційної діяльності та/або недодержання режиму охорони заповідних природних комплексів та об'єктів;

- самовільний дозвіл на здійснення мисливства в межах об'єктів природно-заповідного фонду;

- неякісний контроль за підготовкою, розробкою та веденням Літопису природи об'єкту природно-заповідного фонду, що призвело до внесення недостовірної або неповної інформації чи кількісних даних; 
- використання власних коштів об'єктів природно-заповідного фонду або коштів екологічних фондів не за призначенням або з порушенням вимог чинного законодавства;

- незабезпечення правильного застосування норм екологічного, природоохоронного, трудового, господарського, соціального, пенсійного, цивільного, адміністративного та іншого законодавства України, що стосується прав та законних інтересів працівників установ природнозаповідного фонду;

- систематичне ігнорування заходів по актам прокурорського реагування, депутатським зверненням, окремим ухвалам, рішенням, постановам, ухвалам суддів, відповідних документів інших правоохоронних та органів виконавчої влади, місцевого самоврядування, громадськості з питань порушення природоохоронного законодавства;

- систематичне порушення вимог охорони праці та техніки безпеки працівників установ природно-заповідного фонду, що призвело до травмування працівників або смертельних наслідків;

- систематичне порушення виконання науково-дослідних, відновлювальних, лісо- i гідромеліоративних робіт, заходів з охорони природних екосистем від порушень режиму території, робіт із захисту природних екосистем від шкідників та хвороб;

- порушення порядку приймання-передачі заповідних територій, що призвело до загибелі природних екосистем, комплексів чи об'єктів;

- відсутність контролю за дотриманням підприємствами, установами, організаціями при веденні ними на території об’єкту природно-заповідного фонду господарської діяльності, правил пожежної безпеки, безпеки праці і санітарних правил;

- низький рівень керівництва та неякісний контроль за роботою служби державної охорони об'єкту природно-заповідного фонду в частині систематичного оформлення посадовими особами служби державної охорони протоколів про притягнення до адміністративної відповідальності 3 порушенням вимог чинного законодавства у галузі охорони довкілля і використання природних ресурсів, а також порушення процедури вилучення у порушників предметів і знарядь незаконного використання природних ресурсів, транспортних засобів, незаконно добутої продукції, відповідних документів;

- нездійснення заходів щодо збереження занесених у Червону книгу України зникаючих i рідкісних видів рослинного та тваринного світу, рослинних угруповань, типів природних середовищ;

- порушення процедури ведення документації щодо державного обліку земель природнозаповідного фонду, державного кадастру природно-заповідного фонду і галузевого ведення стану і використання земель природно-заповідного фонду.

Дуже слушно, було б включити до контракту вимогу, що керівник який був звільнений за порушення вимог контракту в частині порушення природоохоронного законодавства не має право у майбутньому посідати керівні посади в установах природно-заповідного фонду.

Однак, сторони, домовляючись про умови контракту, не повинні залишати без уваги, що у відповідності зі ст. 9 КЗПП України [10] трудовий контракт не може містити умови, які погіршують положення працівника в порівнянні з чинним законодавством України, що має враховуватись при укладанні контрактів у природоохоронній сфері.

Висновки та перспективи подальших досліджень. Аналіз трудових правовідносин показує, що контрактна форма найму найбільш доцільна в тих випадках, коли йдеться про наймання висококваліфікованих спеціалістів, на яких покладаються важливі обов'язки і яким необхідно створити особливий режим роботи, що серед іншого передбачає додаткове матеріальне стимулювання та посилену відповідальність сторін. Трудовий контракт може містити і додаткові умови, наявність яких необов'язкова, що конкретизують обов'язки сторін (наприклад, угода про іспит із метою перевірки відповідності працівника виконуваній роботі, про перепідготовку, навчання іншим професіям (спеціальностям), підвищенні кваліфікації, продовження додаткової відпустки, режим робочого часу й часу відпочинку та інше). 
У контракті з працівниками природоохоронної сфери можуть обумовлюватися і соціальнопобутові умови робітників природно-заповідного фонду, наприклад, виділення садової ділянки, автомобіля, поліпшення житлових умов, продаж акцій по номінальній вартості, установлення доплат до соціальних пенсій, захист від інфляційних процесів та інше. Може також передбачатися переїзд працівника в інший природоохоронний заклад та іншу місцевість.

Деталізація та індивідуалізація трудових відносин, зокрема у природоохоронній сфері сприяла б прозорості, законності побудови таких відносин в нашій державі, надала б змогу більшій кількості осіб реалізувати свої здібності до праці на найбільш вигідних умовах, розбудові засад громадянського суспільства та правової капіталістичної держави в цілому. Вважаємо доцільним впровадження низки важелів, щодо персоніфікації відповідальності для працівників природоохоронної сфери, а також обгрунтування відповідних мотиваційних інструментів.

\section{ЛІТЕРАТУРА}

1. Болотіна Н.Б. Трудове право України: Підручник.- 2-ге вид., стереотип / Н.Б. Болотіна // К.: Бікар, 2004. -725 с.

2. Луценко А. Правове регулювання контрактної форми трудового договору: деякі проблеми і шляхи їх вирішення/ А. Луценко // Право України. - 2009. -N7. - C.44-46.

3. Гаврилюк О. Особливості припинення дії трудового контракту / О. Гаврилюк // Право України. - 2009. -№ 8. - С. 74-76.

4. Закон України "Про природно-заповідний фонд України" від 16.06.1992p., № 2456-XII // Відомості Верховної Ради України (ВВР). - 1992. - № 34. - Ст. 503. - [Електронний ресурс]. - Режим доступу: http://zakon5.rada.gov.ua/laws/show/2456-12.

5. Постанова Кабінету Міністрів України від 02.08.1995 № 597 «Про Типову форму контракту 3 керівником підприємства, що є у державній власності» [Електронний ресурс]. - Режим доступу: http://zakon3.rada.gov.ua/laws/show/597-95-\%D0\%BF.

6. Постанова Кабінету Міністрів України від 14.07.2000 № 1127 «Про затвердження Положення про службу державної охорони природно-заповідного фонду України». - [Електронний ресурс].Режим доступу: http://zakon2.rada.gov.ua/laws/show/1127-2000-\%D0\%BF

7. Довідник кваліфікаційних характеристик професій працівників, затверджений Державною службою заповідної справи від 12.09.2003 за погодженням з Міністерством праці та соціальної політики України. Випуск 3. Розділ "Заповідна справа". - Київ, 2003. - 42с.

8. Єдиний державний реєстр судових рішень України. - [Електронний ресурс]. - Режим доступу: http://www.reyestr.court.gov.ua/Page/1

9. Постанова Кабінету Міністрів України від 15 липня 1997 року № 764 "Про затвердження переліку категорій та посад працівників залізничного транспорту, які працевлаштовуються за контрактною формою трудового договору". - [Електронний ресурс]. - Режим доступу: http://zakon5.rada.gov.ua/laws/show/764-97-\%D0\%BF.

10. Кодекс законів про працю України від 10.12.1971//Відомості Верховна Ради Української РСР (ВР УРСР).-1971.- ст.375. - [Електронний ресурс]. - Режим доступу: http://zakon5.rada.gov.ua/laws/show/322-08.

11. Постанова Кабінету Міністрів України "Про впорядкування застосування контрактної форми трудового договору" від 19 березня 1994 р. N 170». - [Електронний ресурс]. - Режим доступу: http://zakon2.rada.gov.ua/laws/show/170-94-\%D0\%BF.

12. Конвенція МОП № 158 про припинення трудових відносин з ініціативи роботодавця, ратифіковано Верховною Радою України 16.05.1995p. - [Електронний ресурс]. - Режим доступу: http://zakon5.rada.gov.ua/laws/show/993_005.

13. Наказ Міністерства праці України "Про затвердження типової форми контракту 3 працівником" від 15.04.1994 № 23. - [Електронний ресурс]. - Режим доступу: http://zakon0.rada.gov.ua/laws/show/z0084-94. 
14. Закон України „Про залізничний транспорт” від 04.07.1996р., № 273/96-ВР// Відомості Верховної Ради України (ВВР). - 1996.- №40.-Ст.184. - [Електронний ресурс]. - Режим доступу: http://zakon0.rada.gov.ua/laws/show/273/96-\%D0\%B2\%D1\%80.

15. Наказ Державної адміністрації залізничного транспорту України від 04.03.2014 № 056 Ц/од "Про впорядкування застосування контрактної форми трудового договору на залізничному транспорті".

16. Рішення Конституційного суду України у справі за конституційним зверненням Київської міської ради професійних спілок щодо офіційного тлумачення частини третьої статті 21 Кодексу законів про працю України (справа про тлумачення терміну "законодавство") від 09.07.1998 № 12рп/98. Справа № 17/81-97. - [Електронний ресурс]. - Режим доступу: http://zakon3.rada.gov.ua/laws/show/v012p710-98.

17. Гусаров О. С. Розмежування норм трудового та інших галузей права у регулюванні статусу керівника підприємства (установи, організації) / О. С. Гусаров // Акт. пробл. права : зб. наук. пр. Вип. 20. - 2011. - с. 220-227.

18. Малиновська К.А. Особливості контракту з керівником юридичної особи // Право та інновації.- 2014.- № 4 (8).- С. 163-170.

19. Прилипко С. М. Трудове право України : підруч. для студ. юрид. спец. вищ. навч. закл. / С.М. Прилипко, О.М. Ярошенко, І.П. Жигалків, В.А. Прудников. - 5-те вид., допов. - Х. : Право, 2014. $-760 \mathrm{c}$.

\section{REFERENCES}

1. Bolotina, N. B. (2004). Trudove pravo Ukrayiny: Pidruchnyk.- 2-ge vyd., stereotyp [The Labor Law of Ukraine ( ${ }^{\mathrm{d}}$ ed.,rev)]. Kyiv, Ukraine: Bikar [in Ukrainian].

2. Lucenko, A. (2009). Pravove regulyuvannya kontraktnoyi formy trudovogo dogovoru: deyaki problemy i shlyaxy yix vyrishennya [The Legal adjusting of labour contract form: some problems and ways of their decision]. Pravo Ukrayiny, 7, 44-46 [in Ukrainian].

3. Gavrylyuk, O. (2009). Osoblyvosti prypynennya diyi trudovogo kontraktu [The action stopping features of labour contract]. Pravo Ukrayiny, 8, 74-76 [in Ukrainian].

4. Zakon Ukrayiny "Pro pryrodno-zapovidnyj fond Ukrayiny" [Law of Ukraine on Nature Reserve Fund of Ukraine] № 2456-XII (1992, June 16). Vidomosti Verkhovnoyi Rady Ukrayiny, 34, 503 [in Ukrainian].

5. Postanova Kabinetu Ministriv Ukrayiny «Pro Typovu formu kontraktu z kerivnykom pidpryyemstva, shho ye u derzhavnij vlasnosti» [Resolution of Cabinet Ministers of Ukraine about the typiform of contract with the enterprise leader in a public domain] № 597. (1995, August 2) [in Ukrainian].

6. Postanova Kabinetu Ministriv Ukrayiny «Pro zatverdzhennya Polozhennya pro sluzhbu derzhavnoyi oxoron pryrodno-zapovidnogo fondu Ukrayiny» [Resolution of Cabinet Ministers of Ukraine about claim of state guard Nature Reserve Fund of Ukraine] № 1127. (2000, July 14) [in Ukrainian].

7. Dovidnyk kvalifikacijnyx xarakterystyk profesij pracivnykiv, zatverdzhenyj Derzhavnoyu sluzhboyu zapovidnoyi spravy za pogodzhennyam z Ministerstvom praci ta socialnoyi polityky Ukrayiny [Reference book of qualifying descriptions of workers professions, ratified by Government service of the protected business]. (2003, September 12 ). Kyiv: Ministerstvo praci ta socialnoyi polityky Ukrayiny [in Ukrainian].

8. Yedynyj derzhavnyj reyestr sudovyx rishen Ukrayiny [The Single state register of Ukraine's court decisions]. Retrieved from: http://www.reyestr.court.gov.ua/Page/1 [in Ukrainian].

9. Postanova Kabinetu Ministriv Ukrayiny "Pro zatverdzhennya pereliku kategorij ta posad pracivnykiv zaliznychnogo transportu, yaki pracevlashtovuyutsya za kontraktnoyu formoyu trudovogo dogovoru" [Resolution of Cabinet Ministers of Ukraine about list claim of categories and positions the railway transport workers, which works in the labour contract form] № 764. (1997, July 15) [in Ukrainian]. 
10. Kodeks zakoniv pro pracyu Ukrayiny [Labor Code of Ukraine]. (1972, June 1). Vidomosti Verkhovnoyi Rady RSR, 49-50, 375 [in Ukrainian].

11. Postanova Kabinetu Ministriv Ukrayiny "Pro vporyadkuvannya zastosuvannya kontraktnoyi formy trudovogo dogovoru" [Resolution of Cabinet Ministers of Ukraine about application organization of labour contract form] № 170. (1994, March, 19) [in Ukrainian].

12. Konvenciya MOP pro prypynennya trudovyx vidnosyn $\mathrm{z}$ iniciatyvy robotodavcya, ratyfikovano Verxovnoyu Radoyu Ukrayiny [Convention of international organization of labour protection about labour relations stopping on employer initiative] № 158. ( 1995, May 16) [in Ukrainian].

13. Nakaz Ministerstva praci Ukrayiny "Pro zatverdzhennya typovoyi formy kontraktu z pracivnykom" [Order of Labour Ministry of Ukraine about the claim of typiform contract with a worker] № 23.(1994, April,15) [in Ukrainian].

14. Zakon Ukrayiny „Pro zaliznychnyj transport” [Law of Ukraine on Railway Transport] № 273/96VR. (1996, July 14). Vidomosti Verkhovnoyi Rady Ukrayiny, 40,184 [in Ukrainian].

15. Nakaz Derzhavnoyi administraciyi zaliznychnogo transport Ukrayiny "Pro vporyadkuvannya zastosuvannya kontraktnoyi formy trudovogo dogovoru na zaliznychnomu transporti" [Order of railway transport state administration of Ukraine about application organization of labour contract form on a railway transport] № $056 \mathrm{Cz} /$ od. (2014, March 4) [in Ukrainian].

16. Rishennya Konstytucijnogo sudu Ukrayiny u spravi za konstytucijnym zvernennyam Kyyivskoyi miskoyi rady profesijnyx spilok shhodo oficijnogo tlumachennya chastyny tretoyi statti 21 Kodeksu zakoniv pro pracyu Ukrayiny (sprava pro tlumachennya terminu "zakonodavstvo") [Decision of the Ukraine's Constitutional court in business after the constitutional appeal of the Kyiv's council trade unions in relation to official interpretation the third part $21^{\text {th }}$ article of a Labour Code of Ukraine (on the right about interpretation the term "legislation")]. (1998, July 9). Case № 17/81-97 [in Ukrainian].

17. Gusarov, O.S. (2011). Rozmezhuvannya norm trudovogo ta inshyx galuzej prava u regulyuvanni status kerivnyka pidpryyemstva (ustanovy, organizaciyi) [Differentiation norms labour and other fields of law in adjusting of leader status enterprise (establishments, organizations)]. Aktyalni problemy prava, 20, 220-227 [in Ukrainian].

18. Malynovska, K.A. (2014). Osoblyvosti kontraktu z kerivnykom yurydychnoyi osoby [Features of contract with the legal entity leader]. Pravo ta innovaciyi, 4 (8), 163-170 [in Ukrainian].

19. Prylypko, S.M. , Yaroshenko, I.P., Zhygalkiv, V.A. \& Prudnykov, V.A. (2014). Trudove pravo Ukrayiny : pidruch. dlya stud. yuryd. specz. vyshh. navch. zakl. [The Labor Law of Ukraine. $5^{\mathrm{d}}$ ed., rev.)]. Kharkiv: Pravo [in Ukrainian]. 